\title{
Effect of metiamide on basal and stimulated serum cholecystokinin levels in duodenal ulcer patients
}

\author{
R. W. SPENCE, L. R. CELESTIN, AND R. F. HARVEY \\ From the Department of Gastroenterology, Frenchay Hospital, Bristol, and Department of Medicine, \\ Bristol Royal Infirmary, Bristol
}

SUMMARY Serum cholecystokinin (CCK) levels were measured in 10 patients with chronic duodenal ulcers, fasting and at intervals after two standard test meals $(300 \mathrm{ml}$ of $40 \mathrm{mmol} / \mathrm{l}$ phenylalanine solution), one given before and one during $\mathrm{H}_{2}$-receptor blockade with metiamide (200 mg four times a day). Fasting serum CCK levels were lower in all patients during treatment with metiamide (the mean level falling from $306.0 \pm 102.0$ (SEM) to $82.1 \pm 23.6 \mathrm{pg} / \mathrm{ml}$ after treatment $(\mathrm{P}<0.01)$ ). In contrast, peak serum CCK levels after the meal were not significantly different $(7400 \pm 1141$ $\mathrm{pg} / \mathrm{ml}$ before treatment and $7569 \pm 1293 \mathrm{pg} / \mathrm{ml}$ on metiamide). We conclude that in duodenal ulcer patients CCK secretion under basal conditions may be in part dependent on stimulation of the small intestinal mucosa by gastric acid, but that, after an amino acid meal, gastric acid secretion is less important in determining the amount of CCK released.

Acid is a known stimulus for CCK release under experimental circumstances (Wang and Grossman, 1951; Berry and Flower, 1971; Wormsley, 1971; Konturek et al., 1974; Barbezat and Grossman, 1975), but the relative importance of this effect in physiological situations is still somewhat uncertain. Previous studies have all recorded the effects of introducing acid into the small intestine. As an alternative approach, we have studied the effect on serum CCK of decreasing endogenous gastric acid secretion by histamine $\mathbf{H}_{2}$-receptor blockade with metiamide (Black et al., 1973; Mainardi et al., 1974; Milton-Thompson et al., 1974; Celestin et al., 1975 ) in patients with chronic duodenal ulceration.

\section{Methods}

The studies were carried out in 10 patients, who were taking part in an open trial of metiamide in chronic duodenal ulcer disease. After an overnight fast a nasogastric tube was passed and screened into position in the antrum. The stomach contents were aspirated and an aliquot retained for $\mathrm{pH}$ measurement. A test meal consisting of $300 \mathrm{ml}$ of $40 \mathrm{mmol} / 1$ phenylalanine was then warmed to $3 i^{\circ} \mathrm{C}$ and delivered rapidly through the nasogastric tube. Small .(10 ml) samples of gastric contents were aspirated at fixed intervals $(10,20,30,45,60,90$,

Received for publication 14 July 1976 and 120 minutes) after the test meal, and returned to the stomach after measurement of their $\mathrm{pH}$ by an automatic pH meter (Radiometer, Copenhagen). Blood samples were obtained via an indwelling intravenous cannula, fasting and at the same intervals as the gastric aspirates, and after separation the serum samples were stored at $-20^{\circ} \mathrm{C}$. After the initial test meal, treatment with metiamide, $200 \mathrm{mg}$ four times a day, was started and continued for at least two months (64 \pm 4.7 days). A second test meal was then given in exactly the same way as before, except that on this occasion an oral dose of metiamide $200 \mathrm{mg}$ was given in $25 \mathrm{ml}$ water one hour before the start of sampling. The CCK levels in all the serum samples from the whole study were later measured in the same batch by radioimmunoassay (method published in detail-Harvey et al., 1974a), and expressed as serum CCK-like immunoreactivity in terms of a CCK-33 standard derived from highly purified hormone (batch of 11-11-1970) supplied by Professor V. Mutt. Because at least two varieties of CCK are present in the body (Mutt and Jorpes, 1968; Debas and Grossman, 1973; Harvey et al., 1974b) and are measured by this assay to differing degrees, and because no standard preparation of CCK is currently available, it is not at present possible to give absolute figures for CCK levels in tissues or serum when using this assay, and, as with other radioimmunoassays for which properly evaluated standard preparations are not available, 
all figures should be regarded as relative rather than absolute (Harvey et al., 1974a). The significance of the differences in CCK levels before and during treatment with metiamide was tested by three different statistical methods $-t$ test (parametric), paired $t$ test, and Wilcoxon rank test (non-parametric).

\section{Results}

Treatment with metiamide produced the expected inhibition of acid secretion, and the mean antral hydrogen ion concentration (derived from antral pH values) was lower at all times after the meal during the period of $\mathrm{H}_{2}$-receptor blockade. Figure 1 illustrates the mean hydrogen ion concentrations \pm SEM before and during treatment. Fasting CCK levels fell in all patients during treatment (mean level falling from $306.0 \pm 102 \cdot 0$ (SEM), median 189 , picograms per $\mathrm{ml}$ to $82 \cdot 1 \pm 23 \cdot 6$, median $57 \mathrm{pg} / \mathrm{ml}$ (Wilcoxon rank test: $\mathbf{P}<0.01$ ) (Fig. 2). In contrast, peak serum CCK levels after the test meal were not significantly altered $(7 \cdot 40 \pm 1 \cdot 14$ $\mathrm{ng} / \mathrm{ml}$ before treatment and $7.57 \pm 1.29 \mathrm{ng} / \mathrm{ml}$ after metiamide). The average time from ingestion of the meal to the time at which the peak serum CCK level was reached was $34.5 \pm 4.3$ minutes before treatment and $34.0 \pm 3.2$ minutes after metiamide. Figure 3 illustrates the mean CCK levels at each sampling time (it does not show the true mean peak values above, as peak values were reached at different times in different individuals). CCK levels at 90 and 120 minutes were also significantly lower during treatment $(\mathrm{P}<0.01,<0.02$ respectively by all three statistical methods employed).

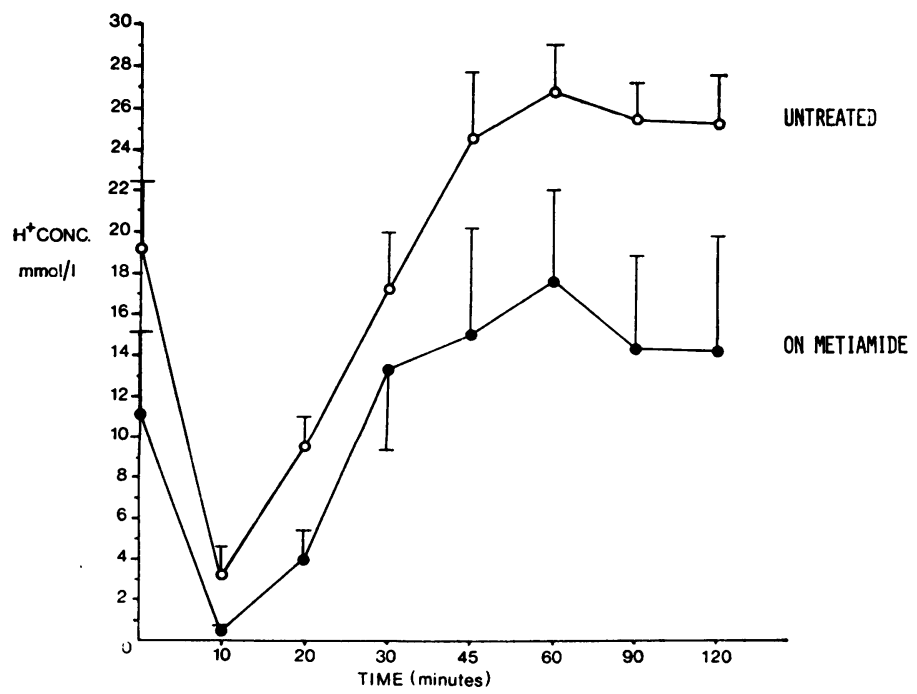

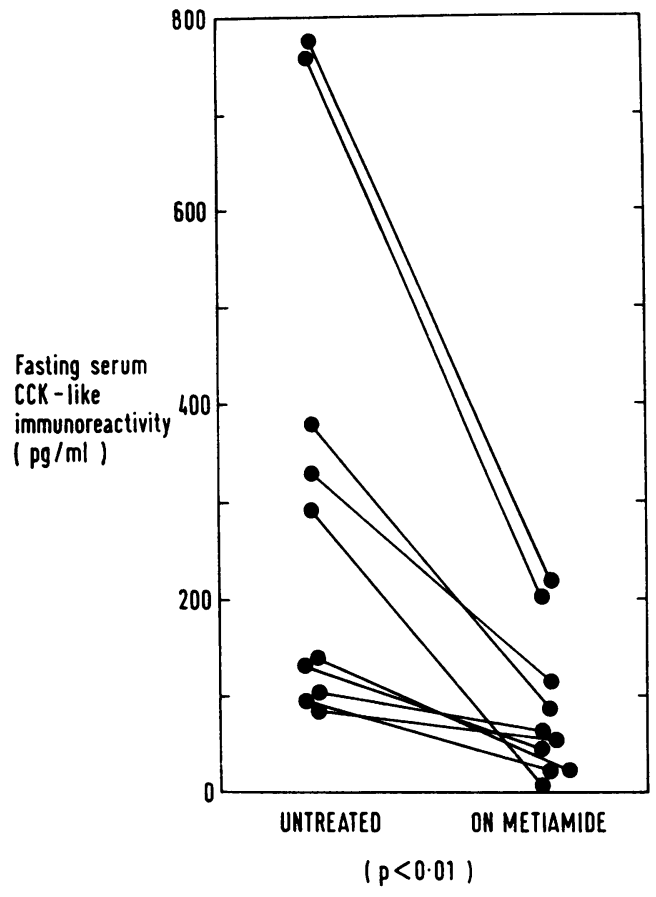

Fig. 2 Fasting serum CCK-like immunoreactivity before and during treatment with metiamide in duodenal ulcer patients.

\section{Discussion}

The fact that fasting serum CCK levels fell after $\mathrm{H}_{2}$-receptor blockade in each of the 10 patients
Fig. 1 Hydrogen ion concentrations (mean $\pm S E M)$ during test meal in the 10 subjects before treatment and after two month' therapy, with metiamide $0.8 \mathrm{~g}$ daily. 


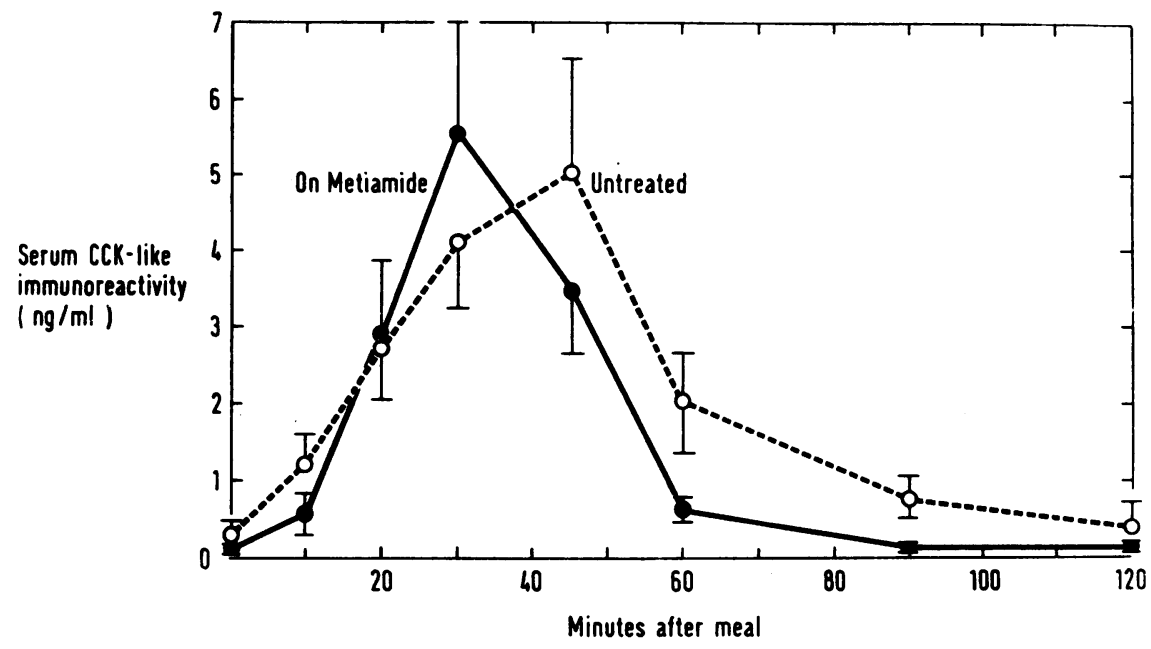

Fig. 3 Serum CCK-like immunoreactivity (mean $\pm S E M$ ) in the 10 subjects after the two test meals.

suggests that metiamide may reduce the basal rate of CCK secretion. Other possible explanations-for example, that metiamide increases the rate of metabolism of CCK-seem less likely. A reduction in the rate of CCK secretion might be due to a direct effect of metiamide on the CCK cell, but this also seems improbable, as CCK release after the test meal was not inhibited by metiamide. The finding that fasting serum CCK levels are decreased by metiamide is consistent with the hypothesis that the entry of gastric acid into the duodenum stimulates CCK release under physiological circumstances. Such a mechanism might be expected to be more important in fasting subjects than after food, as after meals the amount of unbuffered acid entering the duodenum is probably not normally enough to stimulate release of significant amounts of CCK (Barbezat and Grossman, 1975). In patients with the Zollinger-Ellison syndrome (Thompson et al., 1973) or pancreatic exocrine deficiency (Harvey et al., 1973) raised fasting serum CCK levels have been found, and in both these conditions the contents of the upper small intestine are more acid than in normal circumstances. The findings of the present study suggest that release of CCK by acid might contribute to the raised serum levels found in such patients, although it is possible that in some patients with the Zollinger-Ellison syndrome the tumour secretes CCK as well as gastrin, as raised plasma levels may be found in such patients even after total gastrectomy (Thompson et al., 1975).

Patients with duodenal ulceration secrete more trypsin than do control subjects, in response to acid in the small intestine (Thjodleifsson and Wormsley, 1975), so the higher fasting CCK levels in untreated duodenal ulcer patients may in part reflect an increased reactivity of the $\mathrm{CCK}$ cell to the action of acid. In this study CCK levels at 90 and 120 minutes were also significantly higher before treatment in conjunction with a significantly higher acidity, perhaps indicating that an increased reactivity of the CCK cell in these patients is again revealed in the later stages of the response to an amino acid meal. Because CCK probably exists in the body in more than one form (Mutt and Jorpes, 1968; Debas and Grossman, 1973; Harvey et al., 1974b), and because the different forms may vary in their halflives in the blood, a change in the type of CCK secreted by duodenal ulcer patients might occur as a result of treatment with metiamide, and this also could possibly account for the observed changes in fasting serum cholecystokinin levels. Further studies have not been possible, as metiamide has now been withdrawn from use, after reports of transient agranulocytosis (Forrest et al., 1975). However, cimetidine, another $\mathbf{H}_{2}$-receptor blocking agent, is currently being introduced (Burland et al., 1975; Henn et al., 1975; Spence et al., 1976) and may prove suitable for further studies of the effects of acid on the small intestine.

We are very grateful to Lyn Dowsett for technical help, to Smith Kline and French and the Medical Research Council for financial support, and to Professor Viktor Mutt for the highly purified cholecystokinin used in the assay.

\section{References}

Barbezat, G. O., and Grossman, M. I. (1975). Release of cholecystokinin by acid. Proceedings of the Society for Experimental Biology and Medicine, 148, 463-467.

Berry, H., and Flower, R. J. (1971). The assay of endogenous 
cholecystokinin and factors influencing its release in the dog and cat. Gastroenterology, 60, 409-415.

Black, J. W., Duncan, W. A. M., Emmett, J. C., Ganellin, C. R., Hesselbo, T., Parsons, M. E., and Wyllie, J. H. (1973). Metiamide, an orally active histamine $\mathrm{H}_{2}$-receptor antagonist. Agents and Actions, 3, 133-137.

Burland, W. L., Duncan, W. A. M., Hesselbo, T., Mills, J. G., Sharpe, P. C., Haggie, S. J., and Wyllie, J. H. (1975). Pharmacological evaluation of cimetidine, a new histamine $\mathrm{H}_{2}$-Receptor antagonist, in healthy man. British Journal of Clinical Pharmacology, 2, 481-486.

Celestin et al. (1975). (Multicentre Trial). Treatment of duodenal ulcer by metiamide: a multicentre trial. Lancet, 2, 779-781.

Debas, H. T., and Grossman, M. I. (1973). Pure cholecystokinin: pancreatic protein and bicarbonate response. Digestion, 9, 469-481.

Forrest, J. A. H., Shearman, D. J. C., Spence, R., and Celestin, L. R. (1975). Neutropenia associated with Metiamide (Letter). Lancet, 1, 392-393.

Harvey, R. F., Dowsett, L., Hartog, M., and Read, A. E. (1973). A radioimmunoassay for cholecystokininpancreozymin. Lancet, 2, 826-828.

Harvey, R. F., Dowsett, L., Hartog, M., and Read, A. E. (1974a). Radioimmunoassay of cholecystokinin-pancreozymin. Gut, 15, 690-699.

Harvey, R. F., Dowsett, L., and Read, A. E. (1974b). Studies on the nature of cholecystokinin-pancreozymin in small-intestinal mucosal extracts (Abstract). Gut, 15, 838-839.

Henn, R. M., Isenberg, J. I., Maxwell, V., and Sturdevant, R. A. L. (1975). Inhibition of gastric acid secretion by cimetidine in patients with duodenal ulcer. New England Journal of Medicine, 293, 371-375.
Konturek, S. J., Radecki, T., and Thor, P. (1974). Comparison of endogenous release of secretin and cholecystokinin in proximal and distal duodenum in the dog. Scandinavian Journal of Gastroenterology, 9, 153-159.

Mainardi, M., Maxwell, V., Sturdevant, R. A. L., and Isenberg, J. I. (1974). Metiamide, an $\mathrm{H}_{2}$-receptor blocker, as inhibitor of basal and meal-stimulated gastric acid secretion in patients with duodenal ulcer. New England Journal of Medicine, 291, 373-376.

Milton-Thompson, G. J., Williams, J. G., Jenkins, D. J. A., and Misiewicz, J. J. (1974). Inhibition of nocturnal acid secretion in duodenal ulcers by one oral dose of Metiamide. Lancet, 1, 693-694.

Mutt, V., and Jorpes, J. E. (1968). Structure of porcine cholecystokinin-pancreozymin. 1. Cleavage with thrombin and with trypsin. European Journal of Biochemistry, 6, 156-162.

Spence, R. W., Creak, D. R., and Celestin, L. R. (1976). Influence of a meal on the absorption of cimetidine, a new histamine $\mathrm{H}_{2}$-receptor antagonist. Digestion, 14, 127-132.

Thjodleifsson, B., and Wormsley, K. G. (1975). Response to jejunal acidification in patients with duodenal ulcer and normal subjects (Abstract). Gut, 16, 829.

Thompson, J. C., Fender, H. R., Ramus, N. I., Villar, H. V., and Rayford, P. L. (1975). Cholecystokinin metabolism in man and dogs. Annals of Surgery, 182, 496-504.

Wang, C. C., and Grossman, M. I. (1951). Physiological determination of release of secretin and pancreozymin from intestine of dogs with transplanted pancreas. American Journal of Physiology, 164, 527-545.

Wormsley, K. G. (1971). Reactions to acid in the intestine in health and disease. Gut, 12, 67-84. 